\title{
Sloths of the Atlantic Forest in the sixteenth and seventeenth centuries
}

\author{
DANIELLE O. MOREIRA ${ }^{1,2}$ and SÉRGIO L. MENDES ${ }^{3}$ \\ ${ }^{1}$ Programa de Pós-Graduação em Ciências Biológicas (Biologia Animal), Universidade Federal \\ do Espírito Santo, Av. Fernando Ferrari, 514, 29075-910 Vitória, ES, Brasil \\ ${ }^{2}$ Duke University, Nicholas School of the Environment, 308 Research Dr., LSRC, Room A322, Durham, NC 27708, USA \\ ${ }^{3}$ Universidade Federal do Espírito Santo, Departamento de Ciências Biológicas, \\ CCHN, Av. Fernando Ferrari, 514, 29075-910 Vitória, ES, Brasil
}

Manuscript received on October 12, 2015; accepted for publication on January 2, 2016

\begin{abstract}
Sloths were a curiosity item for Europeans in the $16^{\text {th }}$ and $17^{\text {th }}$ centuries, and several descriptions of them exist in bestiaries and texts of that time. Here, we assemble the descriptions and drawings of sloths from the travellers and naturalists of those centuries in the Brazilian Atlantic Forest. The sloth was a novelty to the European audience, and it was described in many strange and inaccurate ways: as a monster, a beast, or an odd child. It served as a source of admiration, amusement, and confusion among naturalists and travellers of the $16^{\text {th }}$ and $17^{\text {th }}$ centuries. We also raised the question about the identity of Carolus Clusius' sloth, a drawing published in Exoticorum libri decem (1605). We compared his drawing with earlier depictions and descriptions, from André Thevet (1516-1590) to George Marcgrave (1610-1644). We present evidence to validate the first drawing of the maned sloth, completed 206 years before the official taxonomic description.
\end{abstract}

Key words: Bradypus, Brazil, Carolus Clusius, Georg Marcgrave, History of Zoology, naturalists.

\section{INTRODUCTION}

Renaissance science opened a new world of diversity between the end of the $15^{\text {th }}$ century and the beginning of the $16^{\text {th }}$ century. At that time, naturalists, explorers and travellers brought news and curiosities from new lands to Europe, including the strange and peculiar animals found in their explorations. Those animals, essentially new to the Europeans, were described in zoological studies published following the form of medieval bestiaries: books that represented animals - real or not — in symbolic

Correspondence to: Danielle de Oliveira Moreira

E-mail: daniomoreira@gmail.com and allegorical ways. The organization and origin of these bestiaries followed, in general, the Naturalis Historia, an encyclopaedia of Pliny, The Elder (23 A.D. - 79 A.D.) - a model for all other encyclopaedias (Gudger 1924, Assunção 2000) — the anonymous Greek volume called the Phisiologus ( $2^{\text {nd }}$ century A.D.), and the Etymologiae from Saint Isidore of Seville (c. 560 A.D. - 636 A.D.), among others (Varandas 2006).

As exploration expanded, the animals of the New World — the Americas — began to be included in these publications (Enenkel and Smith 2007). They were present especially in the natural history writings of the Swiss Conrad Gesner (1516- 
1565), and the Dutch Carolus Clusius (1526-1609). Because many adventurers and explorers travelled to the New World, "exotic" singular and anomalous specimens or artefacts of nature became objects of inquiry and part of the cabinet of curiosities that increasingly became fashionable in Renaissance Europe (Gesteira 2008, Costa 2009). It was in this historical context that the Portuguese and foreign writers of the $16^{\text {th }}$ and $17^{\text {th }}$ centuries recorded the nature of Brazil. One of the most interesting mammals that caught the attention of travellers and naturalists was the sloth.

After European arrival to the Americas, several authors from the $16^{\text {th }}$ and $17^{\text {th }}$ centuries mentioned the sloth in their stories and books. The first to do so was Gonzalo Fernández de Oviedo y Valdés (14781557 ) in his Historia general y natural (General and Natural History of the Indies) of 1526 . Oviedo, who spent many years on the island of Hispaniola and other regions of the Central America, wrote about the sloth, or as he called it, the perico ligèro (or periquito ligèro) (Ashworth Jr 1985, Myers 2007). He even drew the animal (Figure 1) in a simple illustration.

During the two first centuries of colonization, most of the journals and books published from travellers that visited the Brazilian Atlantic Forest were purely reports describing the colony, or remarking on the strange ecology of the New World. Because of the nature of these writings, many of the texts provide limited insight into the natural history of the animals in question. However, these documents can still provide important information valuable to modern zoological studies, especially about species occurrences.

The most famous illustration of a sloth from this era is likely that of Charles de l'Écluse. Better known as Carolus Clusius, he was one of the most influential botanists and naturalists of the $16^{\text {th }}$ and $17^{\text {th }}$ centuries, and he held a special interest in the exotic flora and fauna from outside of Europe (Ommen 2009). Exoticorum libri decem: quibus anima-

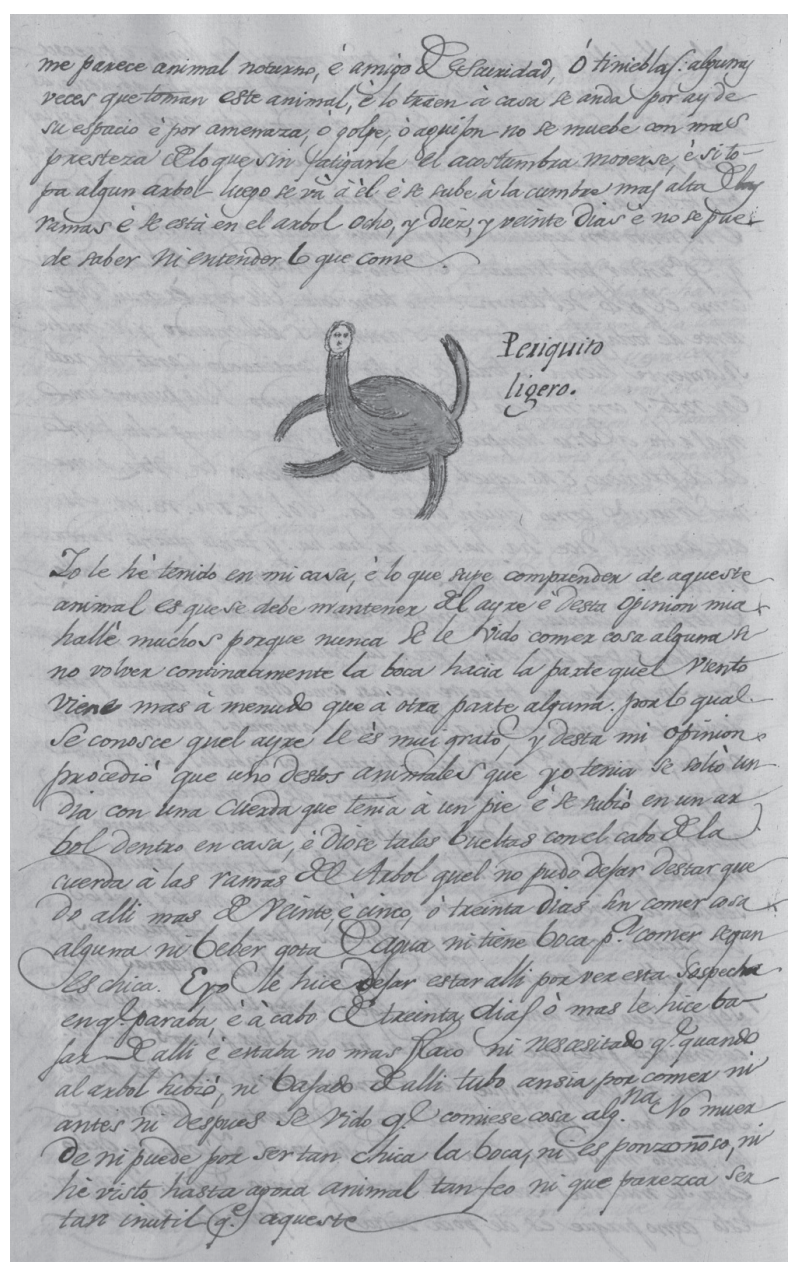

Figure $1-18^{\text {th }}$ century drawing of a sloth (perico ligero or periquito ligero). Juan Bautista Muñoz's copy of Fernández de Oviedo's "General and Natural History of the Indies" (M-RAH, 9/4786, folio $166 \mathrm{v}^{\mathrm{o}}$ ). Copyright: Real Academia de la Historia, Spain.

lium, plantarum, aromatum, aliorumque peregrinorum fructuum historiae describuntur (hereafter Exoticorum), published in 1605 (see Clusius 1605), is the most comprehensive publication about the plants and animals of the New World, South-East Asia, and Africa of its era.

Clusius, however, was not a traveller, and many of his reports did not reflect first-hand knowledge of the species he described. He never left Europe (Kusukawa 2007, Ommen 2009), and therefore, was dependent on books, correspondence, and either live or dead specimens that he received from his many contacts abroad in order to obtain 
information (Egmond 2007, Kusukawa 2007). Considering the lack of opportunity, he had to study his specimens first-hand or in loco, Clusius still described many details of his focal species quite thoroughly, also providing figures.

This study brings together descriptions and drawings of sloths of the Brazilian Atlantic Forest region of the $16^{\text {th }}$ and $17^{\text {th }}$ centuries. The Atlantic Forest was the first Brazilian region discovered by the oversea explorers since the colonization by the Portuguese in 1500 . We also raised the question about the identity of Carolus Clusius' sloth, published in Exoticorium, and propose the taxonomic identity of the Clusius' drawing to be the maned sloth (Bradypus torquatus). We investigated historical records of the two species of sloths that occur in the Atlantic Forest - the maned sloth, Bradypus torquatus, and the brown-throated sloth, Bradypus variegatus. We consulted historical records in books, journals and illustrations of travelers, settlers and naturalists that visited the Brazilian Atlantic Forest in the $16^{\text {th }}$ and $17^{\text {th }}$ centuries. We focused our research in the published material from André Thevet, Jean de Léry, José de Anchieta, Pêro de Magalhães Gandavo, Fernão Cardim, Gabriel Soares de Souza, Ambrósio Fernandes Brandão, and George Marcgrave.

\section{RESULTS AND DISCUSSION}

\section{SLOTHS IN THE HISTORY OF THE ATLANTIC FOREST}

In the Brazilian Atlantic Forest, the French André Thevet (1516?-1592), in his book Singularitez de la France Antarctique (Thevet 1557, 1558a, b) was the first to write about a misshapen creature called Haüt or Haüthi, whose head is similar to a child. Thevet informed that the Native Americans named the animal by a tree called amahut since the sloth lives on those trees. Thevet continues to give more information about the species, describing the sloth's long front and hind limbs, and its three digits, a characteristic from the Bradypodidae family.
Another Frenchman, Jean de Léry (15341613), also mentioned the sloth as a big animal with human face, although he called it Hay. Léry published his journal in 1578 called Histoire d'vn Voyage fait en la Terre dv Bresil, 21 years after Thevet's. The two authors went to Brazil during the French colonisation attempt (the 'France Antarctique' in 1555) where the city of Rio de Janeiro would be founded in 1565, commanded by Nicolas Durand de Villegaignon (1510-1571).

Thevet and Léry's reports about the sloth and other subjects are very similar in many ways, which caused Thevet to accuse Léry of plagiarism (Perrone-Moisés 1996). Both reported that the sloth had a human face, long claws, fur of a bear, a short tail, and that it could be domesticated. According to the authors, the Native Americans carried the animal on their shoulders, supporting its long claws on their skin. They also reported that nobody had seen the sloth feeding, thus surmising that the animal must subsist on air. However, Thevet added that some people believed sloths fed on the leaves of the tree amahut (known today as embaúba, from the genus Cecropia), although he did not seem so sure of that report.

André Thevet attempted to reproduce images of the animal twice, but these were not as accurate as in his descriptions. The first was an iconography from Les singularitez de la France Antarctique (Thevet 1557, 1558a, b) (Figure 2a). The image illustrates one animal in the foreground standing on its four legs, and another one in the background on a tree. Thevet illustrated the sloths with a human and hairy face and with long claws. The second image is from La Cosmographie Vniverselle d'André Thevet Cosmographe $d v$ Roy (1575) (Figure 2b). This time, Thevet's sloth had great proportions and it was described as terribly fierce (Ashworth Jr 1985). Other authors reproduced his illustration or a new version of it, including Conrad Gesner in his Icones animalium quadrupedum viviparorum et oviparorum (1560) (Figure 3a), and even Léry himself, in his Histoire d'un voyage faict in la 
terre du Bresil (Figure 3b) (Ashworth Jr 1985). In these latter one, sloths were illustrated in trees and standing on the ground, among evil spirits tormenting the Native Americans. The image shows the sloth's face to be much more human than in Thevet's illustration.

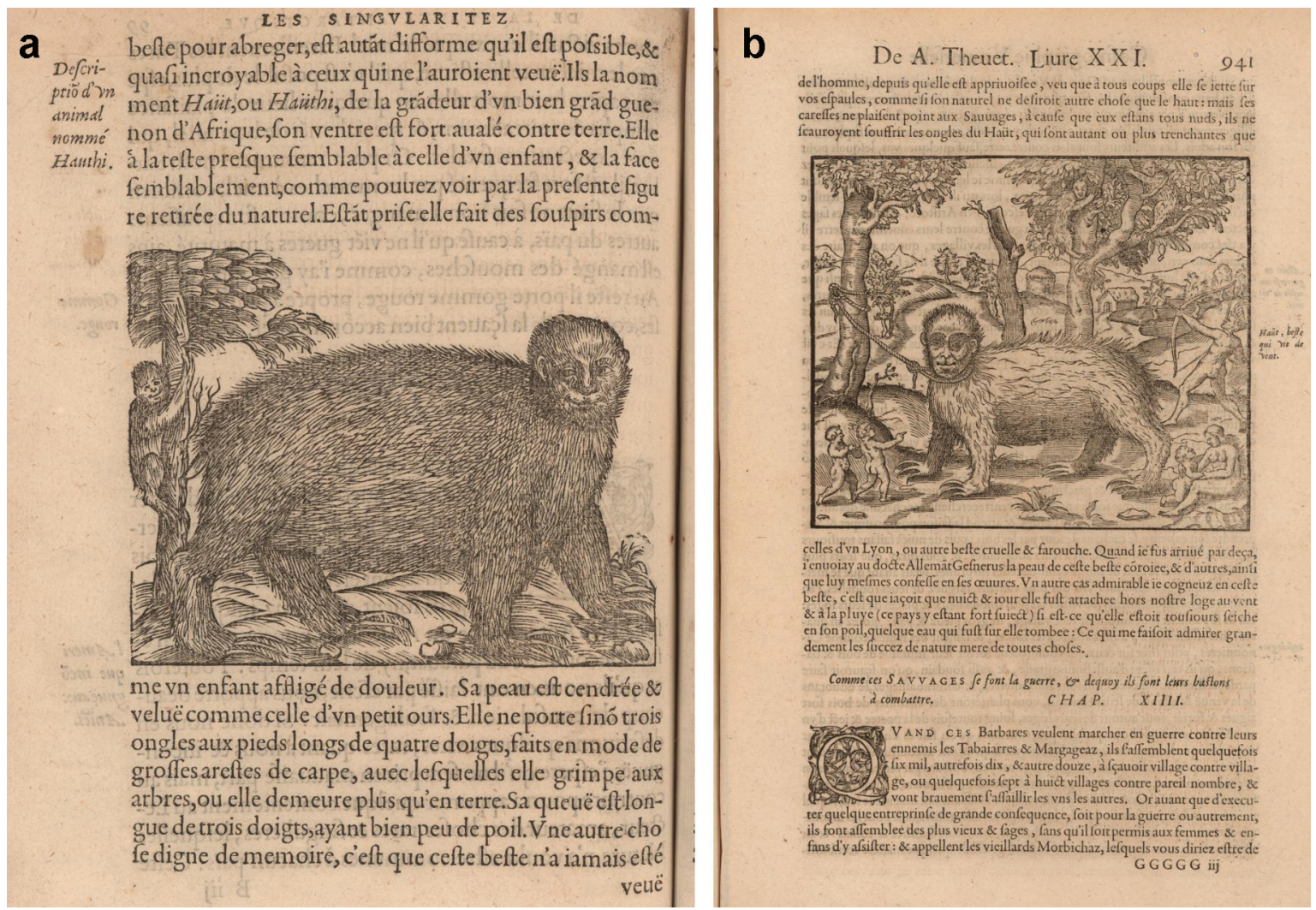

Figure 2 - Bradypus (haüthi). Drawings of André Thevet in his books (a) Les Singularitez de la France antarctique, autrement nommée Amerique, \& de plusieurs Terres \& Isles decouvertes de nostre temps (1558, leaf 99) and (b) Cosmographie Universelle (1575, leaf 941). Courtesy of the John Carter Brown Library at Brown University.

a

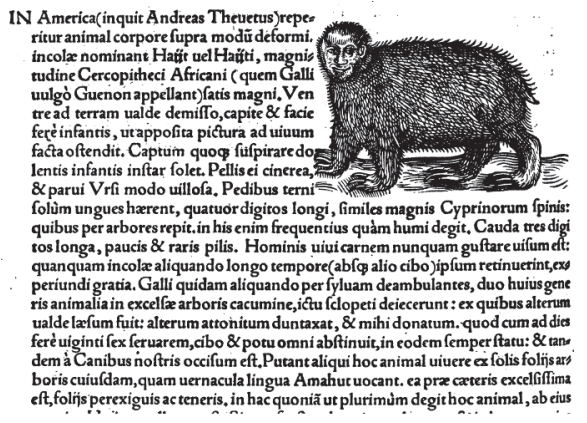

b

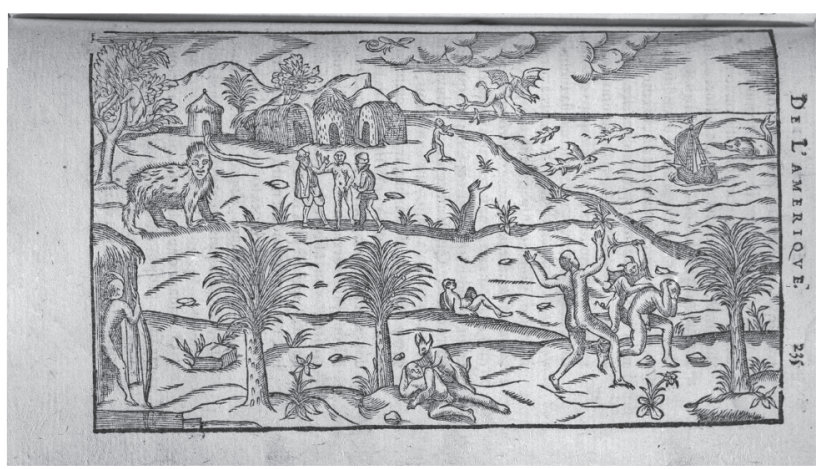

Figure 3 - (a) Haüt or Haüti. Iconography present in Icones animalium quadrupedum viviparorum et oviparorum from Conrad Gesner (1560, p. 96). Public Domain: http://books.google.com. (b) Hay. Sloths on the ground and on the tree, flying fishes, and demons tormenting humans. Iconography in Jean de Lery's book Histoire d'vn Voyage fait en la Terre dv Bresil (1580, p. 235). Courtesy of the John Carter Brown Library at Brown University. 
In 1560, the Spanish Jesuit José de Anchieta (1534-1597) wrote the famous letter of São Vicente - Epistola quam plurimarum rerum naturalium quae S. Vicenti (nunc S. Pauli) provinciam incolunt (Letter about several natural productions inhabiting the Province of São Vicente (now São Paulo)). The letter described to the General Priest of the Captaincy of São Vicente, the many animals that inhabited that region. It is the first lengthy report on the Brazilian animals (Paiva 2003), including the sloth. According to Anchieta, the Native Americans called it aig, and the Portuguese preguiça. It was an animal slower than a snail, had a face similar to a woman, long and strong nails, and, contradicting Thevet and Lery's assumption, Anchieta wrote that the animal fed on leaves of trees (Anchieta 1933, p. 119).

Later, Pêro de Magalhães Gândavo (1540? -1579?), a historian and Portuguese chronicler who lived in Brazil probably between 1558 and 1572, published in 1576 the book Historia da Provincia de Santa Cruz (History of the Province of Santa Cruz) (Papavero and Teixeira 2014). He was the first Portuguese to publish a printed book about Brazil (Almaça 2002). In this book, he wrote about strange animals never seen in other places, including an animal referred to as a sloth (perguiça). According to Gândavo (1576), sloths are animals with ugly faces and very long claws. Gândavo (1576) stated that this animal "walks with its belly touching the ground, without standing up like the other animals" (p. 23), giving the right impression that sloth could not support its weight when on the ground. The author also commented that sloths live in trees, feeding on their leaves, and are slow to climb up or down. He described the sloth with "a long hair in the back of the head", which may implicate the maned sloth, Bradypus torquatus, as Nomura (1996) suggested. We assume this feature attracted the attention of Gândavo because such hair should be different from the ones that covered the animal's body. Supporting the likelihood of his correct identification, we know that Gândavo lived for more than 10 years in the Bahia province, a region of Atlantic Forest where both the maned sloth and the brown-throated sloth occur.

Gabriel Soares de Souza (1540?-1592), a Portuguese farmer, merchant, and naturalist made a complete description of the sloth in his book, Tratado Descriptivo do Brazil em 1581 (A Descriptive Treatise of Brazil in 1581), published in 1587. According to him, ahy was how the Native Americans called the sloth, while the Portuguese, preguiça (Souza 1851). This is the first text that does not compare the sloth's face to a human. Instead, Souza compares the sloth's head to a cat (Souza 1851, p. 257). Souza mentions that the sloth gives birth to one offspring and the young keeps holding onto the mother's neck until it can be independent.

Souza's text does not have many details that can fully confirm the taxonomic identity of the sloth that he was referring to, but his brief description is clear enough to assume that the animal he cites is Bradypus variegatus, the brownthroated sloth. According to Souza (1851), the sloth had "Gadelhas covering his eyes" (p. 257). The Portuguese word for gadelhas means a portion of hair, and B. variegatus's main identifying characteristic is a black band of hair around the eyes. Souza gives further details of the animal's habits, also contradicting Thevet and Lery's assumption, and instead stating that the sloth feeds "each afternoon". Like Gândavo, Souza also writes that the sloth never stands on its feet when on the ground.

During the 1580s, the Portuguese Jesuit Fernão Cardim (1548/1549-1625) wrote two treatises and letters that came to be known only by the end of the nineteenth century as the Tratados da Terra e Gentes do Brasil (Treatises of the land and people of Brazil). There, with great humour, he described the sloth as a very ugly animal, like a "hairy $\operatorname{dog}(\ldots)$ whose face looks like a barely touched 
woman" (Cardim 2009). He also wrote that the sloth walks with its "belly on the ground" and that it is a very slow animal. Cardim further declared that was not possible for the animal to survive in Portugal because the sloth only ate "fig leaves." (Likely, he meant the leaves of Cecropia).

In the $17^{\text {th }}$ century, the Portuguese Ambrósio Fernandes Brandão (1555-?) went to Brazil as a sugar mill lord in Olinda and Paraíba from 1583 to 1587 and from 1607 to 1618 , respectively (Mello 1997, Fernandes et al. 2011). He wrote about the sloth in his book Diálogos das grandezas do Brasil (Dialogues of the greatness of Brazil), completed in 1618 (Silva 1997, Fernandes et al. 2011). Unlike Souza (1851), who reported that the sloth does not ever go down to the ground (p. 257), Brandão described the ahum or preguiça as "an animal [...] that to climb or descend from a tree, even short distances, takes at least two days' time, and on the ground requires the same to move a short distance [...]" (Brandão 1997, p. 202). Because Brandão lived in Olinda and Paraíba, on the northeastern coast of Brazil, it is likely that he was describing the brown-throated sloth.

Writing from the perspective of the Dutch in Brazil, George Marcgrave (1610-1644) made an impressive and detailed morphological description of the brown-throated sloth in his book Historia rerum naturalium Brasiliae of 1648 (Figure 4a). His descriptions cover a breadth of information, from measurements of the body, limbs and teeth, to coat coloration and behaviour (see Marcgrave 1648). In the Dutch collection of natural history drawings, the Libri Picturati, it is further possible to identify Dutch explorers' and naturalists' illustrations as being representative of the brownthroated sloth. The first such illustration is in Libri Principis and was painted by Marcgrave himself. The picture shows one sloth on the ground, crawling, and another climbing a tree (this image is also illustrated in the frontispiece of Historia rerum naturalium Brasiliae, Figure 4b). In the Theatrum rerum naturalium Brasiliae, another volume of Libri Picturati, an illustration shows a sloth with its abdomen on the ground, body and head facing forward and its limbs stretched forward, reproducing the movement of this animal when on the ground (Figure 4c). The authorship of that drawing is attributed to Albert Eckhout (Gesteira 2008).

\section{CluUsius' SLOTH}

In Marcgrave's book, the image that appears on page 221 of Historia rerum naturalium Brasiliae (see Marcgrave 1648) is itself a reproduction from the book Exoticorum by Carolius Clusius. Exoticorum has two woodcut drawings of sloths (see Clusius 1605). The first, from page 111 (Figure 5a) does not much resemble a sloth, but rather a goat or sheep. This inaccuracy can be attributed to the fact that Clusius drew his first image from a stuffed specimen in the collection of Rutger Jansz in Amsterdam (Ommen 2009). Afterward, he realized his drawing of a long-preserved animal was not accurate (Ommen 2009), and began to seek newer and better specimens.

The second sloth woodcut (Figure 5b), found on page 373 of Exoticorum, has something different from other earlier illustrations. The sloth represented in the second woodcut has black hairs projecting from the head and back of the neck - again, the classic characteristic indicating a maned sloth. According to Ommen (2009), Clusius drew the sloth from a dead specimen acquired by the famous Dutch florist, painter and naturalist collector, Emmanuel Sweerts. The sloth had been taken from the New World to Europe but did not survive the voyage, and Sweerts had purchased its preserved body in Amsterdam. With a new specimen as a model, Clusius drew a new version of a sloth. However, because he did not know the natural history and behaviour of sloths, he drew the animal standing on its four limbs. Sloths are known to crawl when they are on the ground, instead of supporting their body by standing on their feet. 


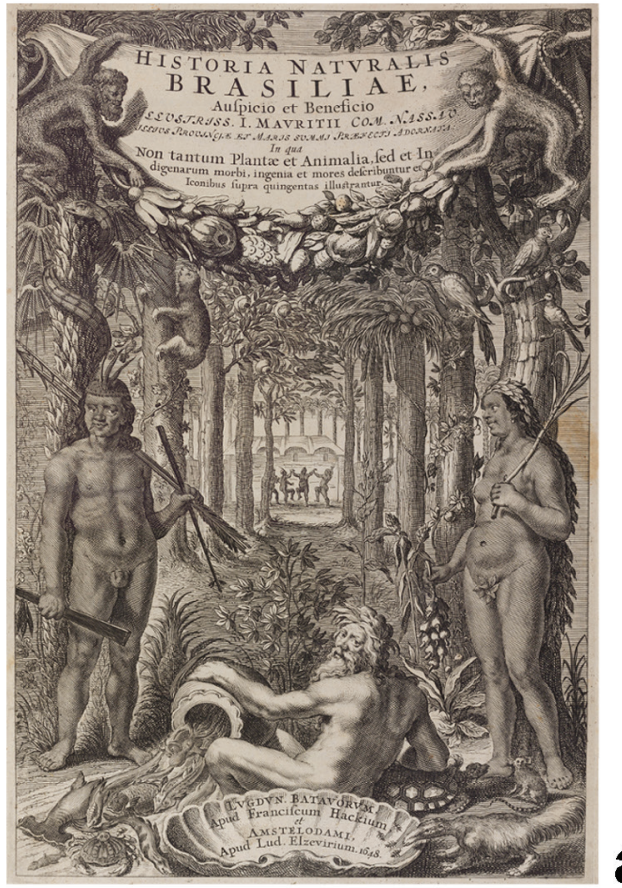

a
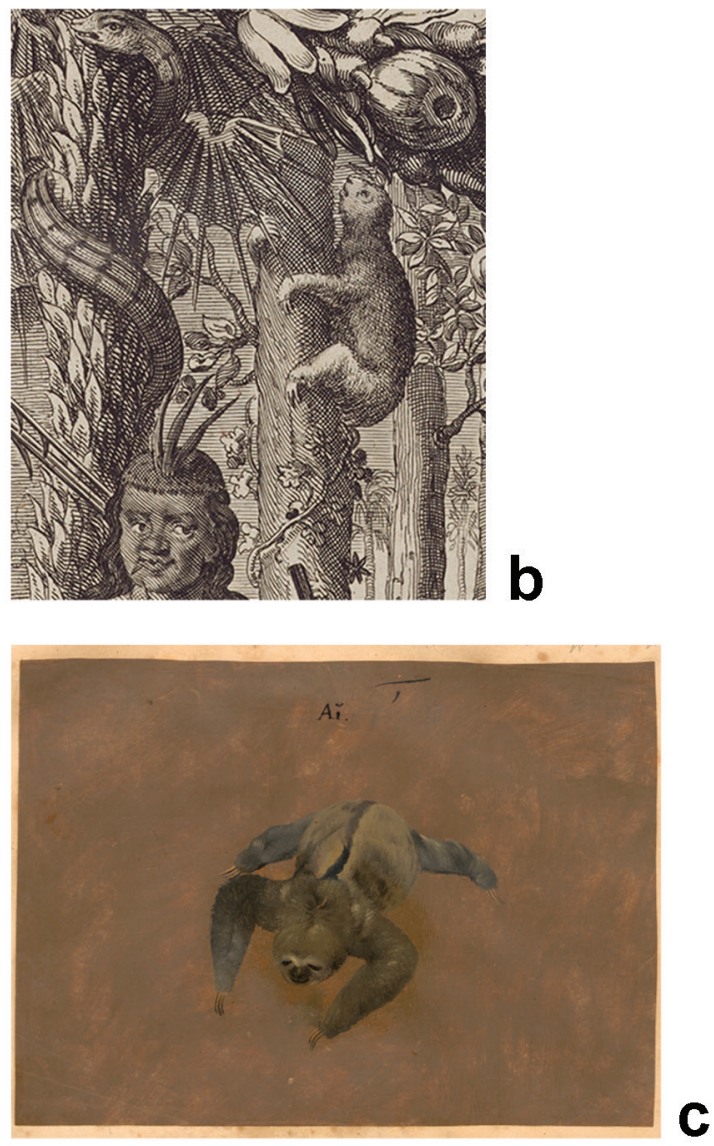

Figure 4 - (a) Frontispiece of Historia Naturalis Brasiliae by Willem Piso and George Marcgrave (1648) with decorative elements, including animals like the sloth. Courtesy of the John Carter Brown Library at Brown University. (b) The image of sloth represents the brown throated sloth Bradypus variegatus, a possibly drawing by George Marcgrave published originally in Libri Principis ('Handbook' I fol. 30r, Libri Picturati A36), compiled around 1640. (c) The brown throated sloth Bradypus variegatus. Possibly drawing of Albert Eckhout in Theatrum rerum naturalium Brasiliae (Libri Picturati A 34) (1660 - 1664). Copyritght: Jagiellonian Library, Krákow.
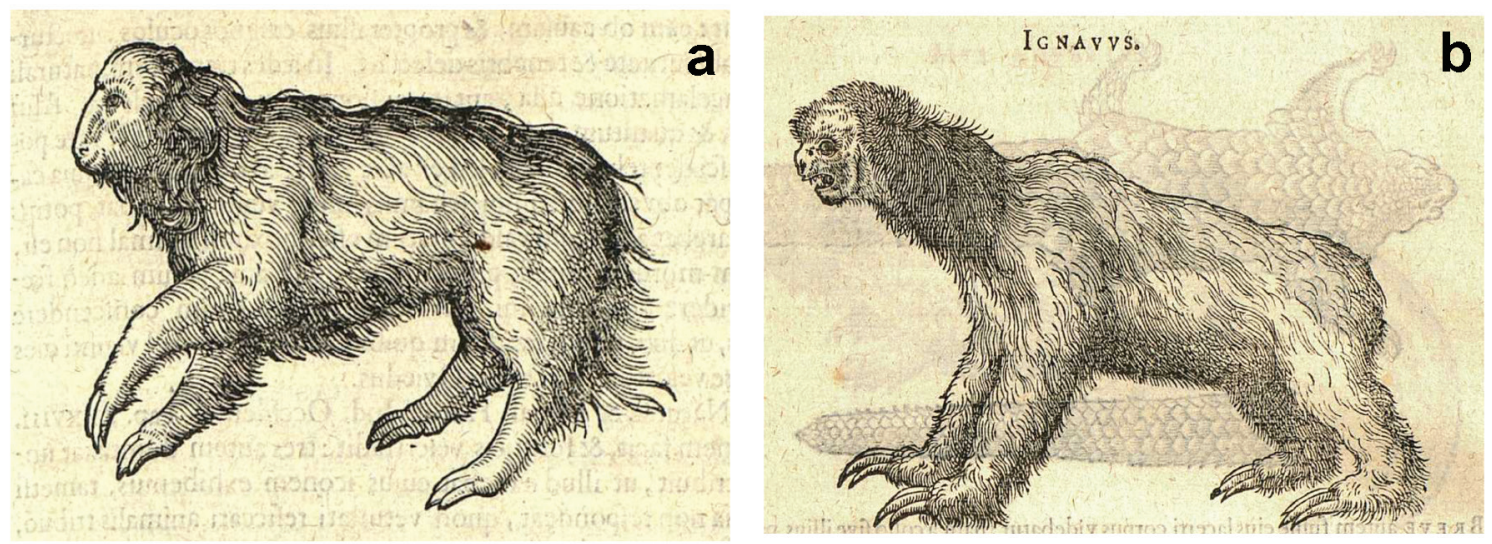

Figure 5 - (a) and (b) Ignavus. Woodcut of sloths by Carolus Clusius: (a) page 111 and (b) page 373 of Exoticorium Decem libri (1605). Public Domain: http://bibdigital.rjb.csic.es/ing/Libro.php?Libro=4727\&Pagina=1. 
The exact origin of that sloth is still a mystery. If Clusius was at least careful about reproducing the most striking feature of the animal — the black fur around its neck - it is likely that it came from somewhere in the Brazilian Atlantic Forest, between the states of Rio de Janeiro and Sergipe, where the maned sloth is endemic. This may be the first illustration of this species, made 206 years before the taxonomic description by Illiger (Illiger 1811, p. 108).

This second sloth drawing became very popular among naturalists, and several other books of natural history reproduced the same image (Ashworth Jr 1985), including the Historia rerum naturalium Brasiliae, from George Marcgrave, as referenced above. In fact, even with at least two good iconographies of the brown-throated sloth painted during the Dutch colonization in northeastern Brazil, Johannes de Laet, editor of Historia rerum naturalium Brasiliae, chose the already-famous Clusius' illustration to include in his volume.

\section{CONCLUSIONS}

Historical written documents, literary works, and paintings or engravings from the $16^{\text {th }}$ and $17^{\text {th }}$ centuries' travellers can give modern researchers a general idea of the ecological landscape of early colonial Brazil. Those were the first discoveries and impressions of animals in the literature for the New World, and it is worth noting that most of the descriptions were based on first-hand observations (Costa 2009). Most of the authors cited here travelled to Brazil during colonization attempts (i.e. André Thevet, Jean de Léry, and George Marcgrave), on missionary orders (i.e. José de Anchieta and Fernão Cardim), or for settling, exploration, and commercial activities (i.e. Gabriel Soares de Souza and Ambrósio Fernandes Brandão), or political matters (i.e. Pêro de Magalhães Gandavo).
This era of pre-Linnaean zoology was not fundamentally interested in the accurate investigation of nature itself. Instead, it followed the traditions of Renaissance classicism, which emphasizes the author's stories and knowledge (Almaça 2002). In that time, faunal records tended to focus on the symbolic meaning of the animals represented, rather than attempting to reflect precisely their zoological reality or their natural-historical conceptualization (Enenkel and Smith 2007).

In the 16 th and 17 th centuries, the sloth was an animal that served as a source of admiration, amusement, and confusion among naturalists and travellers. The animal was known by its indigenous name - haüt, hay, aig (and other variations) or by its Portuguese name - preguiça, which means laziness. The main sloth features that called the naturalists and travellers attention were its "human" face, long claws, and its slow movements. The sloth, a novelty to a European audience, was drawn or described in many strange and inaccurate ways: as a monster, a beast, or an odd child. Confusion even shadowed the most educated records of the species - both André Thevet and Clusius, for example, depicted the sloth as a biped - and lack of live specimens for observation made correction difficult. However, even using distorted descriptions about the animal, some reports also brought accurate observations, showing that the authors were curious about the natural history of the species. Gabriel Soares de Souza, for example, gave the most detailed description of a sloth among the sixteenth naturalists, while George Marcgrave was the most important naturalist to study the Brazilian fauna in the first three centuries of colonisation.

In the $16^{\text {th }}$ and $17^{\text {th }}$ century journals and records of naturalists, descriptions and drawings can provide enough information to draw conclusions about the species described, and to assist in our understanding of presence and distribution in the past. In the case of Clusius' second sloth, the illustration adds information that even the description lacks, allowing us to identify the 
species in question as the maned sloth (Bradypus torquatus). Therefore, we can conclude that the Atlantic Forest's endemic maned sloth - today a threatened species - was a curiosity item and one of the many Brazilian species shipped to Europe in the $16^{\text {th }}$ and $17^{\text {th }}$ centuries.

\section{ACKNOWLEDGMENTS}

The authors would like to thank Alexandra Sutton, Stuart L. Pimm, and Karen B. Strier for reviewing the manuscript. The Real Academia de la Historia (Madrid) and the Jagiellonian Library (Krákow) authorised the images reproduction. D.O.M. was a Conselho Nacional de Desenvolvimento Científico e Tecnológico (CNPq/ Brazil) Ph.D. fellow (process number 555144/2009-7 of MCT/CNPq n ${ }^{\circ} 70 / 2008$ ) and a Coordenação de Aperfeiçoamento de Pessoal de Nível Superior (Capes/ Brazil) Ph.D. Fellow (process number 11827/12-2). The research was a part of D.O.M's thesis.

\section{RESUMO}

Preguiças foram itens de curiosidade para os europeus nos séculos XVI e XVII e várias descrições existem em bestiários e textos daquela época. Aqui, nós trazemos as descrições e desenhos de preguiças feitas por viajantes e naturalistas daqueles séculos para a Mata Atlântica brasileira. As preguiças eram uma novidade para o público europeu e foram descritas de várias formas inprecisas e estranhas: como monstros, bestas, ou crianças estranhas. Elas serviram como fonte de admiração, divertimento e confusão entre os naturalistas e viajantes dos séculos XVI e XVII. Também abrimos a discussão sobre a identidade da preguiça de Carolus Clusius, um desenho publicado no Exoticorum libri decem (1605). Nós comparamos esse desenho com representações e descrições anteriores de André Thevet (1516-1590) a George Marcgrave (1610-1644). Nós apresentamos evidências para validar a primeira representação da prequiça-de-coleira, 206 anos antes da descrição taxonômica oficial.

Palavras-chave: Bradypus, Brasil, Carolus Clusius, Georg Marcgrave, História da Zoologia, naturalistas.

\section{REFERENCES}

ALMAÇA C. 2002. A zoologia pré-lineana no Brasil. Lisboa: Museu Bocage, 147 p.

ANCHIETA J. 1933. Cartas, informações, fragmentos históricos e sermões do Padre Joseph de Anchieta, S.J. (1554-1594). Cartas Jesuíticas III. Rio de Janeiro: Civilização Brasileira S.A, 567 p. Available in http://www.brasiliana.usp.br/bbd/ handle/1918/00381630, acessed on: October 12, 2015.

ASHWORTH JR WB. 1985. The persistent beast: recuring images in early zoological illustration. In: Ellenius A (Ed), The Natural sciences and the arts: aspects of interaction from the Renaissance to the 20th century: an international symposium, Uppsala: Acta Universitatis Upsaliensis, p. 46-66.

ASSUNÇÃO P. 2000. A terra dos brasis: a natureza da América portuguesa vista pelos primeiros jesuítas (1549-1596). São Paulo: Annablume, 274 p.

BRANDÃO AF. 1997. Diálogos das grandezas do Brasil. Recife: Editora Massangana, 242 p.

CARDIM F. 2009. Tratados da terra e gente do Brasil. São Paulo: Hedra, 220 p.

CLUSIUS C. 1605. Exoticorum libri decem quibus animalium, plantarum, aromatum, aliorumque peregrinorum fructuum historiae describuntur: Item Petri Bellonii observationes, eodem C. Clusii interprete. Leiden: Officina Plantiniana Raphelengii, $378 \mathrm{p}$.

COSTA PFC. 2009. Secrecy, ostentation, and the illustration of exotic animals in sixteenth-century Portugal. Ann. Science 66: 59-82.

EGMOND F. 2007. Clusius and friends: Cultures of exchange in the circles of European naturalists. In: Egmond F et al. (Eds), Carolus Clusius: Towards a cultural history of a Renaissance naturalist, Amsterdam: Edita - Royal Netherlands Academy of Arts and Sciences, p. 9-48.

ENENKEL KAE AND SMITH PJ. 2007. Introduction: Early Modern Zoology. In: Enenkel KAE and Smith PS (Eds), Early Modern Zoology: The construction of animals in science, literature and the visual arts, vol. 2, Leiden; Boston: Brill, p. 1-12.

FERNANDES ACS, PEREIRA R, CARVALHO IS AND AZEVEDO DA. 2011. O âmbar de Ambrósio Fernandes Brandão: um registro equivocado. Fil Hist Biol 6: 173-187.

GÂNDAVO PM. 1576. Historia da prouincia sãcta Cruz a que vulgarmente chamamos Brasil feita por Pero de Magalhães de Gandavo, dirigida ao muito Ills. Sñor Dom Leonis Pra governador que foy de Malaca e das mais partes do Sul da India. Lisboa: Officina de Antonio Gonsalvez, 48 p.

GESNER C. 1560. Icones animalivm qvadrvpedvm viviparorvm et oviparorvm, qvae in Historiae Animalivm Conradi Gesneri libro I. et II. describvntvr, cvm nomenclatvris singvlorvm latinis, graecis, italicis, gallicis, et germanicis 
plervmque, et aliarvm qvoqve lingvarum, certis ordinibvs digestas. Tiguri [= Zürich]: C. Froschevervs, $126 \mathrm{p}$.

GESTEIRA HM. 2008. Representações da natureza: mapas e gravuras produzidos durante o domínio neerlandês no Brasil (1624/1654). Rev IEB 46: 165-178.

GudGeR EW. 1924. Pliny's Historia Naturalis. The most popular natural history ever published. Isis 6: 269-281.

ILLIGER JKW. 1811. Caroli Illigeri Prodromus Systematis mammalium et avium. Berolini: Sumptibus C. Salfeld, $302 \mathrm{p}$.

KUSUKAWA S. 2007. Uses of pictures in printed books: The case of Clusius' Exoticorum libri decem. In: Egmond $\mathrm{F}$ et al. (Eds), Carolus Clusius. Towards a cultural history of a Renaissance naturalist, eds. Amsterdam: Edita - Royal Netherlands Academy of Arts and Sciences, p. 221-246.

LÉRY J. 1578. Histoire d'vn voyage fait en la terre dv Bresil, avtrement dite Amerique. Contenant la nauigation, \& choses remarquables, veuës sur mer par l'aucteur. La Rochelle: Antoyne Chuppin, 424 p.

MARCGRAVE G. 1648. Historiae rerum naturalium, liber sextus: qui agit de quadrupedibus, \& serpentibus. Historia Naturalis Brasiliae. Lvgdvn[nvm] Batavorvm \& Amstelodami, 293 p.

MELlo JAG. 1997. Introdução: Diálogos das Grandezas do Brasil. In: Diálogos das Grandezas do Brasil, $3^{\text {a }}$ ed., Recife: Massangana, p. XIII-LII.

MYERS KA. 2007. Fernández de Oviedo's chronicle of America: a new history for a New World. Austin: University of Texas Press, $344 \mathrm{p}$.

NOMURA H. 1996. História da Zoologia no Brasil: Século XVI. Coleção Mossoroense, Série C. Mossoró: Fundação Vingt-un Rosado/ ETFRN-UNED, 193 p.

OMMEN K. 2009. The Exotic World of Carolus Clusius (15261609). Leiden: Leiden University Library, 124 p.
PAIVA MP. 2003. José de Anchieta (1534-97): Pioneiro dos estudos sobre a fauna do Brasil. R IHGB 418: 27-54.

PAPAVERO N AND TEIXEIRA DM. 2014. Zoonímia tupi nos escritos quinhentistas europeus. São Paulo: NEHiLP/ FFLCH/USP, 329 p. Available in http://www.usp.br/ nehilp/arquivosdonehilp/NEHiLP_3.pdf, accessed: on December 3, 2015.

PERRONE-MOISÉS L. 1996. Alegres trópicos: Gonneville, Thevet e Léry. Rev USP 30: 84-93.

SILVA LD. 1997. As revelações de Ambrósio. In: Diálogos das grandezas do Brasil, 3 rd ed, Recife: Editora Massangana, p. VII-XII.

SoUZA GS. 1851. Tratado descriptivo do Brazil em 1587. Rio de Janeiro: Typographia Universal de Laemmert, 422 p. Available in http://www.brasiliana.usp.br/ handle/1918/01720400, acessed on: December 3, 2015.

THEVET A. 1557. Les singvlaritez de la France Antarctiqve, avtrement nommée Amerique: \& de plusieurs Terres \& Isles decouuertes de nostre temps. Paris: Chez les heritiers de Maurice de la Porte, $166 \mathrm{p}$.

TheVeT A. 1558a. Les singvlaritez de la France Antarctiqve, avtrement nommée Amerique: \& de plusieurs Terres \& Isles decouuertes de nostre temps. Paris: Chez les heritiers de Maurice de la Porte, au Clos Bruneau, à l'enseigne S. Claude, $166 \mathrm{p}$.

THEVET A. 1558b. Les singvlaritez de la France Antarctiqve, avtrement nommée Amerique: \& de plusieurs Terres \& Isles decouuertes de nostre temps. Anvers: De l'imprimerie Christophe Plantin, a la Licorne d'or, 163 p.

TheVET A. 1575. La Cosmographie Vniverselle d'André Thevet Cosmographe dv Roy, Tome Second, Paris: Guillaume Chaudiere, $468 \mathrm{p}$.

VARANDAS A. 2006. A idade média e o bestiário. Medievalista 2: $1-53$. 